\title{
ANALISIS MODEL RELASIONAL JEJARING SEBAGAI KATALISATOR DALAM MEMBANGUN KINERJA BISNIS
}

\author{
Ahmad Sidiq \\ Program Studi Manajemen, STIE Atma Bhakti Surakarta \\ Email: alqodrani16@gmail.com \\ Handayani Tri Wijayanti \\ Program Studi Akuntansi, STIE Atma Bhakti Surakarta \\ Email: yanidiawan@yahoo.co.id
}

\begin{abstract}
Abstrak
Kesuksesan entrepreneur diukur dari kehandalannya menggabungkan atau mengkombinasikan aset berwujud dan tak berwujudyang dimiliki UKM sehingga mampu mendobrak semua hambatan yang dihadapi UKM yaitu keterbatasan akses pasar dan akses modal, sumber daya yang cenderung rendah, minimnya modal kerja maupun rendahnya kemampuan untuk memanfaatkan peluang pasar yang ada. Berbagai perilaku yang digunakan entrepreneur dalam menjalankan bisnisnya maupun berinteraksi dengan stakeholder mengarah pada relasional jejaring dan kompetensi sosial yang harus dimiliki oleh seorang entrepreneur. Penelitian ini bertujuan untuk menguji faktor yang mampu memperluas relasional jejaring entrepreneur dan faktor konsekuensi dari adanya relasional jejaring yang dimiliki oleh seorang entrepreneur, yang sangat berkaitan dengan pencapaian kinerja bisnis UKM. Populasi penelitian ini adalah UKM sektor manufaktur di wilayah Surakarta dengan sampel sebanyak 127 UKM. Metode pemilihahan sampel adalah convenience sampling dan dianalisis menggunakan Structural Equation Modeling (SEM) dengan bantuan Partial Least Square (PLS) dalam pengolahan data penelitian. Hasil analisis data menunjukkan kinerja bisnis dapat dijelaskan oleh kompetensi sosial, relasional jejaring dan orientasi berbagi pengetahuan sebesar $69.5 \%$. Adapun hasil pengujian hipotesis menunjukkan kinerja bisnis dipengaruhi oleh kompetensi sosial, relasional jejaring dan orientasi berbagi pengetahuan. Selain itu kompetensi sosial berpengaruh pada relasional jejaring dan relasional jejaring memberi pengaruh pada orientasi berbagi pengetahuan.
\end{abstract}

Kata Kunci : kompetensi sosial, relasional jejaring, berbagi pengetahuan, kinerja bisnis

\begin{abstract}
The success of the entrepreneur is measured by reliability merge or combine the tangible assets and intangible owned by SMEs so as to break down all the barriers faced by SMEs is limited access to markets and access to capital, resources tend to be low, the lack of working capital and lack of ability to take advantage of market opportunities. The various behaviors used by entrepreneurs in conducting their business or interacting with stakeholders lead to the relational networking and social competence that an entrepreneur must possess. This study aims to examine the factors that are able to expand the relational network of entrepreneurs and the consequence factors of the existence of relational networks owned by an entrepreneur which are closely related to the achievement of business performance on SMEs. The population of this study is SME manufacturing sector in the Surakarta region with a sample of 127 SMEs. The method of sample selection is convenience sampling and analyzed using Structural Equation Modeling (SEM) with Partial Least Square (PLS) aid in data processing research. The results of data analysis show business performance can be explained by social competence, network relational and knowledge sharing orientation of $69.5 \%$. The results of hypothesis testing show business performance is influenced by social competence, network relational and knowledge sharing orientation. In addition, social
\end{abstract}


competence affects the relational networks and relational networks affect the orientation of knowledge sharing.

Keywords: Social Competence, Network Relational, Knowledge Sharing, Business Performance

\section{PENDAHULUAN \\ Latar Belakang}

Upaya meningkatkan kinerja pada UKM, selalu berkaitan dengan seorang entrepreneur dalam menjalankan bisnis dengan cara menggabungkan sumber daya modal, SDM dan asset-aset lainnya sehingga dapat menciptakan sesuatu yang memiliki nilai lebih dari sebelumnya (Hirsch, 2009). Keberhasilan seorang entrepreneur diukur dari kehandalannya mengombinasikan elemen-elemen tersebut sehingga mampu mendobrak semua hambatan yang dihadapi UKM. Berbagai perilaku yang digunakan entrepreneur tersebut untuk menjalankan bisnisnya maupun berinteraksi dengan stakeholdernya mengarah pada relasional jejaring dan kompetensi sosial yang harus dimiliki oleh seorang entrepreneur.

Jejaring entrepreneur yang dilakukan oleh UKM sangat dibutuhkan karena jejaring akan mengembangkan hubungan UKM dengan organisasi eksternal yang memiliki potensi untuk membantu pengembangan bisnis, kelangsungan hidup, dan pertumbuhan. Fokus pada hubungan eksternal UKM akan melihat betapa pentingnya sumber daya eksternal untuk membantu UKM bergerak untuk peningkatan keberhasilan dan profitabilitas (Street dan Cameron, 2007). Seorang entrepreneur tidak dapat lepas dari adanya relasional jejaring untuk memenuhi kebutuhan akan sumber daya. Dodd et al.,(2002) menyatakan bahwa entrepreneur akan mendapatkan sumber daya yang dibutuhkan dari jejaring yang mereka miliki. Taylor dan Thorpe (2004) menyebutkan bahwa jejaring entrepreneur sangat dibutuhkan oleh perusahaan karena jejaring akan menyediakan entrepreneur akses untuk mendapatkan informasi, peluang bisnis, pasar, ide-ide atau sumber daya yang lain. Hasil dari jejaring entrepreneur yang baik akan sangat berhubungan dengan pertumbuhan dan kesuksesan bisnis (Bruder dan Preisendorfer, 1998).

Melihat pentingnya relasional jejaring bagi kesuksesan bisnis UKM maka perlu di lakukan penelitian lebih lanjut mengenai beberapa faktor yang sekiranya mampu memperluas jejaring entrepreneur dari seorang entrepreneur dan beberapa faktor konsekuensi dari jejaring entrepreneur yang dimiliki oleh seorang entrepreneur. Oleh sebab itu penelitian ini akan akan memperjelas pengaruh kompetensi sosial terhadap relasional jejaring entrepreneur dan kaitannya dengan orientasi berbagi perngetahuan dan kinerja bisnis UKM di wilayah Surakarta sehingga dengan kinerja bisnis UKM yang baik bahkan unggul maka diharapkan UKM di wilayah Kota Surakarta dapat bersaing dalam pasar internasional.

\section{Tujuan Penelitian}

Adapun tujuan dalam penelitian ini adalahuntuk mengetahui pengaruh kompetensi sosial pada relasional jejaring dan kinerja bisnis, pengaruh relasional jejaring terhadap orientasi berbagi pengetahuan dan kinerja bisnis maupun pengaruh orientasi berbagi pengetahuan terhadap kinerja bisnis.

\section{TINJAUAN PUSTAKA}

\section{Resources Base View (RBV)}

RBV menjelaskan bahwa kinerja perusahaan merupakan perpaduan antara sumber daya berwujud dan tidak berwujud perusahaan. Keunggulan kompetitif perusahaan dapat diciptakan dari pengelolaan sumber daya tersebut secara optimal oleh perusahaan. Barney $(1991,2007)$ menyebutkan dalam teori RBV bahwa perusahaan mampu mencapai 
dan mempertahankan keunggulan kompetitif apabila perusahaan memiliki sumber daya nyata atau tidak berwujud yang bernilai, langka, tidak ada bandingannya dan tidak dapat diganti. Keempat point tersebut merupakan asset strategis bagi perusahaan.

Sumber daya tak berwujud merupakan aset strategis untuk mengembangkan keunggulan kompetitif, karena sumber daya ini cenderung langka, berharga, tidak dapat ditiru dan sulit bagi perusahaan lain untuk menggantikannya (Roxas dan Chadee, 2011). Beberapa studi memberikan perhatian lebih pada sumber daya tak berwujud sebagai dasar untuk mengembangkan keunggulan kompetitif (Chrisholm dan Nielsen, 2009; Locket et al., 2009; Newbert, 2007).

\section{Modal Sosial}

Modal sosial merupakan asset yang akan memberi akses bagi perusahaan untuk mendapatkan berbagai sumber daya yang berada di luar jangkauannya jika perusahaan berada dalam berbagai keterbatasannya (Lages et al.,2009; Davidsson dan Honig, 2003). Woolcock (1998) berpendapat bahwa modal sosial akan memberikan manfaat yang menguntungkan karena adanya tindakan bersama.

Modal sosial terkait dengan keuntungan ekonomi dan pengentasan kemiskinan (Fafchamps dan Minten, 2002; Grootaert, 2001). Selain itu Bourdieu (1986) juga berpendapat bahwa keuntungan perusahaan diperoleh dari modal sosial yaitu bersumber dari adanya hubungan perusahaan dengan pihak lain. Modal sosial merupakan salah satu cara untuk mendapatkan sumber daya bagi perusahaan sehingga perusahaan mampu berkembang untuk meningkatkan keunggulan kompetitifnya. Perusahaan yang mengarah pada kegiatan internasional sangat membutuhkan modal sosial seperti jejaring, hubungan informal, hubungan antar perusahaan maupun hubungan manajerial (Ellis, 2010; Pollard dan
Jemicz, 2010). Oleh karena itu dapat dikatakan bahwa tujuan perusahaan yaitu keunggulan kompetitif, eksistensi dan nilai perusahaan akan dapat tercapai apabila perusahaan memiliki modal sosial yang kuat dan erat.

\section{Kompetensi Sosial}

Kompetensi sosial merupakan kemampuan seorang entrepreneur untuk melakukan interaksi atau hubungan dengan stakeholdersnya yang didasarkan pada ketrampilan sosial yang dimiliki (Baron dan Markman, 2003; Manuela et al., 2004; Hakim, 2015). Kompetensi sosial akan dapat berdampak pada kinerja organisasi karena kemampuan entrepreneur ini akan memudahkan entreprenuer beradaptasi dengan individu lain maupun membentuk kesan yang baik pada stakeholder organisasi (Manuela et al., 2004; Meutia, 2013). Mason dan Harisson (2001) berpendapat bahwa perusahaan yang dapat menciptakan kesan yang positif akan memberi sinyal yang baik bagi investor sehingga akan meningkatkan peluang bisnis. Stamatov dan Sariyska (2015) mengklasifikasikan kompetensi sosial menjadi beberapa dimensi yaitu kemampuan komunikasi, kerja sama, harga diri, kemampuan, ketegasan, kontrol diri dan efisiensi diri.

\section{Relasional Jejaring}

Jejaring dapat didefinisikan sebagai interaksi atau hubungan yang memiliki pola antara pelaku-pelaku yang bertindak sebagai individu, kelompok maupun organisasi. Jejaring memiliki beberapa bentuk, antara lain : joint venture, aliansi, subkontrak atau kemitraan. Relasional jejaring organisasi merupakan sebuah pengaturan sukarela dari dua atau lebih perusahaan yang melibatkan pertukaran, sharing produk dan teknologi baru (Weaver et al., 1998 dalam Lukiastuti, 2012).

Relasional jejaring entrepreneur merupakan kemampuan yang dimiliki oleh entrepreneur untuk dapat membangun dan mempertahankan hubungan kerja maupun 
hubungan sosial dengan para stakeholder. Relasional jejaring entrepreneur yang dimiliki entrepreneur perusahaan akan menghasilkan hubungan dengan banyak pihak baik para penyedia sumber daya maupun pihak yang akan memanfatkan output perusahaan. Relasional jejaring entrepreneur yang baik akan membantu perusahaan untuk tetap eksis dalam bisnisnya karena pasokan sumber daya akan tercukupi dan produk yang dihasilkan akan dapat diserap lebih baik dan cepat oleh pelanggan.

\section{Berbagi Pengetahuan (Knowledge Sharing)}

Selain berhubungan dengan manfaat ekonomi, modal sosial juga tidak lepas kaitannya dengan modal manusia (Coleman, 1998; Lin, 1999). Modal manusia dapat berupa keterampilan dan kemampuan maupun pengetahuan. Modal manusia dapat dibentuk dari adanya interaksi dengan orang lain sehingga mampu menghasilkan ketrampilan dan kemampuan untuk membentuk seseorang bertindak dengan cara baru.

Berbagi pengetahuan yang efektif akan membawa pengaruh positif bagi pengetahuan organisasi dan akan meningkatkan kemampuan anggota perusahaan untuk mencapai kinerja yang lebih baik (Jalote, 2003; Horvat et al.,2015). Mathew et al.,(2011) berpendapat bahwa penggabungan pengetahuan seluruh karyawan menjadi pencetus timbulnya peluang baru dan meningkatkan respon positif dalam berpikir inovatif. Sedangkan Lin (2007) berpendapat bahwa kelangsungan hidup organisasi dapat terganggu apabila anggota-anggota organisasi memiliki resistensi dalam berbagi pengetahuan.

\section{Kinerja Bisnis}

Kinerja bisnis sering dilihat hanya dari sisi keuangan saja yaitu mengenai biaya yang harus ditanggung oleh perusahaan. Namun, beberapa peneliti berpendapat bahwa kinerja perusahaan harus dilihat dari berbagai sudut pandang yang berbeda (Nakata et al.,2008; Eskildsen et al., 2003). Kinerja keuangan kurang mampu memberikan keadaan yang lengkap tentang keadaan perusahaan secara menyeluruh (Ishtiaque et al.,2007; Khan et al.,2011).Hal inilah yang menyebabkan pengukuran kinerja perusahaan dilakukan dengan melihat 2 dimensi yaitu dimensi pasar dan keuangan.

\section{Pengaruh Kompetensi Sosial terhadap Kinerja Bisnis}

Kinerja perusahaan yang baik tidak hanya dapat dicapai dengan kompetensi professional namun kompetensi sosial sangat dibutuhkan. Kompetensi sosial akan membantu individu untuk melakukan komunikasi maupun interaksi sosial sehingga mampu untuk menggabungkan pengetahuan yang dimilikinya dengan informasi yang diperoleh dalam proses interaksi sosial tersebut untuk menjadi hal yang positif bagi dirinya. Sejalan dengan penelitian Verbeke et al.,(2011) maupun Yang dan $\mathrm{Wu}$ (2014) menunjukkan individu dengan kompetensi sosial yang tinggi akan lebih mudah mencapai kinerja yang tinggi pula hal ini akan berdampak pada kinerja organisasi. Berdasarkan penjelasan tersebut, hipotesis pertama yang diajukan adalah:

\section{$\mathrm{H}_{1}$ : Kompetensi sosial berpengaruh positif dan signifikan terhadap kinerja bisnis.}

\section{Pengaruh Kompetensi Sosial terhadap Relasional Jejaring Entrepreneur}

Kompetensi sosial merupakan suatu kemampuan yang dimiliki entrepreneur untuk membangun hubungan sosial dan keterkaitan sosial dengan pihak eksternal yaitu supplier, lembaga perbankan, pemerintah, atau organisasi lainnya (Meutia, 2015). Berdasarkan beberapa penelitian terdahulu menyatakan bahwa modal sosial yang tinggi melalui relasional jejaring akan membantu perusahaan untuk mendapatkan akses yang penting dalam mencapai kesuksesan oleh sebab itu 
kompetensi sosial yang dimiliki oleh seseorang akan membantu dalam menciptakan jejaring entrepreneur yang baik (Baron dan Markman, 2003; Muthia, 2013). Selanjutnya menurut Meutia (2015) dikatakan bahwa seseorang yang memiliki kompetensi sosial tinggi akan dapat mengekspresikan lebih banyak perhatian sosial, bersikap lebih simpatik, lebih bermanfaat dan lebih disukai oleh leingkungan sekitar. Berdasarkan uraian teoritis tersebut maka hipotesis kedua adalah:

\section{$\mathrm{H}_{2}$ : Kompetensi sosial berpengaruh positif dan signifikan terhadap relasional jejaring entrepreneur.}

\section{Pengaruh Relasional Jejaring Entre- preneur terhadap Kinerja Bisnis}

Kesuksesan bisnis yang dicapai sangat mungkin tergantung pada kemampuan pemilik untuk mendapatkan akses sumber daya yang diluar kendali perusahaan melalui cara yang paling efisien. Hasil penelitian Watson (2007) membuktikan adanya hubungan signifikan positif antara jejaring dengan kinerja keuangan perusahaan. Biggs dan Shah (2006) melihat bahwa UKM di wilayah Sahara Afrika membutuhkan peran lembaga pendukung baik swasta maupun pemerintah. Kerja sama dengan lembagalembaga tersebut akan meningkatkan kinerja UKM karena kerjasama tersebut akan meningkatkan akses kredit sehingga kebutuhan akan modal usaha terpenuhi. Hal tersebut sejalan dengan penelitian Smirnova et al.,(2011) dan Zohdi et al.,(2013) menyebutkan adanya korelasi positif yang signifikan antara kemampuan relasional jejaring dan kinerja bisnis. Entrepreneur yang menekankan pada peningkatan hubungan dengan organisasi lain sebagai strategi kunci perusahaan akan meningkatkan tingkat keberhasilan perusahaan dan meningkatkan kinerja perusahaan. Berdasarkan uraian teoritis di atas maka hipotesis ketiga adalah:

\section{$H_{3}$ : Relasional jejaring entrepreneur berpengaruh positif dan signifikan terhadap kinerja bisnis}

Pengaruh Relasional Jejaring Entrepreneur terhadap Orientasi Berbagi Pengetahuan

Relasional jejaring mengacu pada kekuatan hubungan sosial antara individu penyedia pengetahuan dan penerima pengetahuan (Wang dan Noe, 2010). Salehi et al.,(2014) berpendapat bahwa ikatan sosial dikembangkan melalui dukungan sosial yang kuat akan menjadi sumber daya dalam hubungan sosial tersebut. Anggota perusahaan dengan ikatan sosial yang kuat mudah meningkatkan perilaku berbagi pengetahuan karena adanya situasi kerja nyaman dan kondusif (Tangaraja et al.,2015; Borges, 2013; Chai et al.,2012). Sedangkan Kale dan Singh (2007) menjelaskan bahwa berbagi pengetahuan dari komunitas interaksi dalam kolaborasi akan berdampak pada keunggulan kompetitif perusahaan. Berdasarkan uraian tersebut, maka hipotesis keempat adalah:

\section{$\mathrm{H}_{4}$ : Relasional jejaring entrepeneur berpengaruh positif dan signifikan terhadap orientasi berbagi pengetahuan}

\section{Pengaruh Orientasi Berbagi Penge- tahuan terhadap Kinerja Bisnis \\ Orientasi berbagi pengetahuan pada} perusahaan akan meningkatkan efektivitas proses pengambilan keputusan. Berbagi pengetahuan akan membuka pikiran anggota perusahaan akan berbagai alternatif penyelesaian masalah sehingga akan menghasilkan pengambilan keputusan yang tepat. Berbagi pengetahuan meningkatkan kolektif pengetahuan dan mengarah pada solusi inovatif sehingga masalah perusahaan dapat tertangani dengan baik dan kinerja perusahaan dapat menjadi baik (Lee et al.,2013; Chou et al.,2009). 
Penelitian Vij (2014) mengindikasikan bahwa orientasi berbagi pengetahuan memiliki hubungan signifikan positif pada kinerja bisnis perusahaan. Pimpinan perusahaan memiliki tugas untuk mendorong karyawan dalam berkomunikasi, berinteraksi dan berbagi ide atau gagasan sehingga akan membuka peluang bisnis dalam upaya untuk meningkatkan kinerjanya. Berdasarkan uraian teoritis maka hipotesis kelima yang diusulkan adalah:

\section{$\mathrm{H}_{5}$ : Orientasi berbagi pengetahuan berpengaruh positif dan signifikan terhadap kinerja bisnis}

\section{Kerangka Pikir}

Penelitian ini meneliti mengenai pengaruh kompetensi sosial, relasional jejaring dan orientasi berbagi pengetahuan terhadap kinerja bisnis perusahaan. Secara piktografis pengaruh tersebut disajikan pada kerangka pemikiran sebagai berikut:

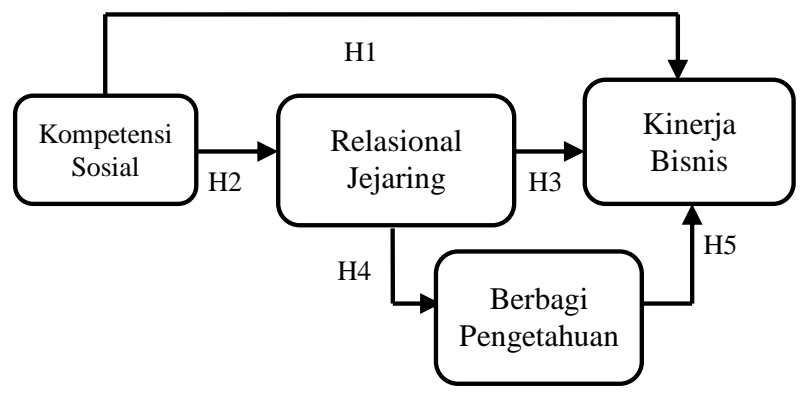

Gambar 1. Model penelitian

\section{METODE PENELITIAN}

\section{Populasi dan Pemilihan Sampel}

Populasi penelitian ini adalah Usaha Kecil Menengah (UKM) sektor manufaktur di Surakarta yang terdaftar pada database Dinas Koperasi dan UMKM Surakarta. Jumlah UKM di Surakarta sebanyak 505 UKM. Adapun jumlah sampel minimal dalam penelitian ini adalah 105 UKM yang diperoleh dari perhitungan $5 \times 21$ indikator penelitian. Pengambilan sampel penelitian dilakukan dengan menggunakan metode convience sampling. Hal ini dilakukan karena adanya keterbatasan waktu dalam melakukan penelitian dengan objek yang masih kurang familier dalam melakukan pengisian kuesioner.

\section{Definisi Operasional dan Pengukuran Variabel Penelitian}

Data primer diukur dengan menggunakan Skala Likert dengan 5 pilihan (dimulai dari 'sangat tidak setuju' sampai dengan 'sangat setuju sekali').

\section{Kompetensi Sosial}

Kompetensi sosial adalah kemampuan seorang entrepenenur dalam berinteraksi secara efektif dengan individu lain didasarkan dengan ketrampilan sosial yang sangat erat (Baron and Markman, 2003). Pengukuran kompetensi sosial dalam penelitian ini mengadopsi penelitian Yang dan Wu (2014) dengan 6 indikator.

\section{Relasional Jejaring Entrepreneur}

Relasional jejaring entrepreneur adalah hubungan yang dimiliki oleh seorang entrepreneur dengan pihak eksternal perusahaan sehingga akan memperlancar dirinya mendapatkan sumber daya penting yang dibutuhkan (Vissa, 2010). Pengukuran relasional jejaring entrepreneur dengan 3 indikator yang diadaptasi dari Meutia (2013).

\section{Orientasi Berbagi Pengetahuan}

Orientasi berbagi pengetahuan diartikan sebagai proses pertukaran dan memperoleh pengetahuan di antara individu-individu melalui cara formal maupun informal dalam dan di antara tim, unit organisasi, dan organisasi (Zaqout dan Abbas,2012). Pengukuran orientasi berbagi pengetahuan dengan 6 indikator yang diadaptasi dari Jian dan Wang (2013).

\section{Kinerja Bisnis}

Kinerja bisnis adalah ukuran seberapa efektif dan efisien perusahaan dalam mencapai tujuan bisnisnya (Nakata et al.,2008). Pada umumnya tujuan bisnis perusahaan yang ingin dicapai adalah maksimalisasi penjualan dan laba. Pengukuran kinerja bisnis perusahaan mengadopsi penelitian dari Nakata et al.,(2008) maupun Zhu dan Nakata (2010). 


\section{Pengujian Kualitas Data}

Kualitas data dilihat dari hasil pengujian reliabilitas maupun validitas. Pada pengujian reliabilitas akan melihat hasil composite reliability dancronbach alpha. Menurut Ghozali (2015), suatu konstruk dikatakan reliable apabila memberikan nilai composite reliability dan cronbach alpha di atas 0.70. Sedangkan pengujian validitas akan melihat hasil loading factor yang menunjukkan convergent validity. Apabila korelasi suatu konstruk dengan indikatornya memiliki nilai lebih tinggi dibandingkan dengan korelasi indikator tersebut dengan konstruk lainnya maka hal ini menunjukkan bahwa konstruk laten mempredikasi indikator pada blok mereka lebih baik dibandingkan dengan indikator di blok lainnya (Ghozali, 2015). Hal tersebut juga menggambarkan bahwa indikator konstruk tersebut valid.

\section{Pengujian Kesesuaian Model}

Goodness of fit model diukur menggunakan R-square variabel laten dependen dengan interpretasi yang sama dengan regresi. Pengujian kesesuaian model juga dengan melihat nilai SRMR, d_ULS, d_G, Chi Square dan NFI.

\section{Pengujian Hipotesis}

Pengujian hipotesis dilakukan dengan Structural Equation Model (SEM) yaitu dengan menggunakan Partial Least Square (PLS). Model struktural dalam penelitian ini dianalisis dengan sofware Smart PLS 3. Adapun persamaan yang dibentuk adalah :

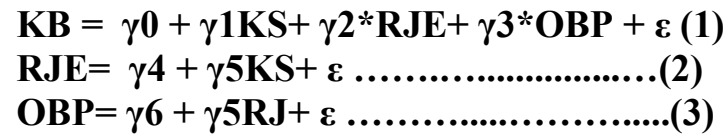

Keterangan : KB : Kinerja Bisnis, RJE : Relasional Jejaring Emtrepreneur, OBP : Orientasi Berbagi Pengetahuan, KS : Kompetensi Sosial, OBP : Orientasi Berbagi Pengetahuan, $\varepsilon$ : Error

Pengambilan keputusan pengujian hipotesis yang diterima didasarkan pada nilai $p$ (probabilitas) dengan nilai signifikansi di bawah 0,05 dan membandingkan antara $\mathrm{t}$ hitung dan $\mathrm{t}$ tabel yaitu nilai $\mathrm{t}$ hitung lebih besar dari t tabel $(1,96)$.

\section{HASIL DAN PEMBAHASAN}

\section{Deskripsi Responden}

Survey dilakukan dengan menggunakan kuesioner secara langsung ke 158 pemilik UKM di wilayah Surakarta. Namun yang kembali hanya 133 kuesioner dengan respon rate sebesar $84 \%$. Terdapat 6 kuesioner yang tidak lengkap sehingga tidak memenuhi syarat dalam pengolahan data. Pada akhirnya, hanya 127 kuesioner yang dapat mewakili 505 UKM di Surakarta dapat digunakan untuk analisis data dalam melakukan pengambilan keputusan dalam uji hipotesis.

Profil dari 127 responden yang berpartisipasi sebagian besar berjenis kelamin wanita yaitu sebanyak 69 orang (54\%). Kondisi ini disebabkan karena usaha UKM dengan segala keterbatasannya membutuhkan adanya ketelatenan tertentu sehingga pada umumnya kemampuan ini lebih banyak melekat dalam diri seorang wanita. Sebagian besar responden berusia diantara 31 - 40 tahun sebanyak 45 orang (35\%), mayoritas tingkat pendidikan responden adalah SMA yaitu sebanyak 64 orang $(50 \%)$. Adapun mayoritas bidang usaha tersebut adalah usaha makanan dan minuman yaitu sebanyak 57 UKM atau sebesar $45 \%$ dengan umur usaha terbanyak adalah 5-10 tahun sebanyak 48 UKM atau $38 \%$. \%). Usaha bidang makanan dan minuman mendominasi pada UKM di Surakarta karena memang Kota Surakarta merupakan salah satu destinasi pariwisata di Jawa Tengah sehingga usaha kuliner merupakan usaha yang sangar erat kaitannya dalam dunia pariwisata.

\section{Hasil Pengujian Kualitas Data}

Pengujian reliabilitas dilakukan dengan melihat nilai composite reliability dan cronbach alpha dari blok indikator yang mengukur masing-masing konstruk. Berdasarkan Tabel 1 maka nilai composite 
reliability dan cronbach alpha menunjukkan nilai yang memuaskan yaitu nilai masing-masing konstruk di atas nilai minimum yaitu 0,70. Selain itu tabel tersebut juga menunjukkan bahwa setiap konstruk memiliki tingkat $\mathrm{t}$ statsitik diatas 1,96. Hal ini dapat dikatakan bahwa terdapat konsistensi dan stabilitas instrumen penelitian yang tinggi atau dapat disimpulkan bahwa keempat konstruk tersebut cukup reliabel untuk dapat digunakan dalam penelitian.

\section{Tabel 1. Hasil Pengujian Reliabilitas}

\begin{tabular}{lcccc}
\hline \multirow{2}{*}{ Konstruk } & \multicolumn{2}{c}{$\begin{array}{c}\text { Composite } \\
\text { Reliability }\end{array}$} & \multicolumn{2}{c}{ Cronbach Alpha } \\
\cline { 2 - 5 } & $\begin{array}{l}\text { Original } \\
\text { Sample }\end{array}$ & $\begin{array}{c}\boldsymbol{t} \text { - } \\
\text { Statistik }\end{array}$ & $\begin{array}{c}\text { Original } \\
\text { Sample }\end{array}$ & $\begin{array}{c}\boldsymbol{t} \text { - } \\
\text { Statistik }\end{array}$ \\
\hline $\begin{array}{l}\text { Kinerja } \\
\text { Bisnis }\end{array}$ & 0.846 & 38.434 & 0.772 & 19.719 \\
\hline $\begin{array}{l}\text { Kompetensi } \\
\text { Sosial }\end{array}$ & 0.867 & 51.519 & 0.815 & 31.411 \\
\hline $\begin{array}{l}\text { Orientasi } \\
\text { Berbagi } \\
\text { Pengetahuan }\end{array}$ & 0.852 & 45.588 & 0.781 & 24.454 \\
\hline $\begin{array}{l}\text { Relasional } \\
\text { Jejaring }\end{array}$ & 0.839 & 34.695 & 0.746 & 17.402 \\
\hline
\end{tabular}

Sumber : Data yang diolah, 2017

Pengujian validitas diukur dengan validitas diskriminan indikator. Validitas diskriminan indikator dapat dilihat dari nilai cross loading konstruk. Tabel 2 menunjukkan bahwa konstruk telah memiliki validitas diskriminan yang tinggi artinya konstruk laten mampu memprediksi indikator pada blok masingmasing lebih baik dibandingkan dengan indikator diblok lainnya. Hal ini menunjukkan bahwa semua indikator telah valid dan dapat digunakan dalam penelitian ini.

\section{Pengujian Kesesuaian Model}

Goodness of fit model diukur menggunakan R-square variabel laten dependen dengan interpretasi yang sama dengan regresi, dijelaskan pada Tabel 3.
Tabel 2. Cross Loading Indikator Antar Konstruk

\begin{tabular}{lcrrr}
\hline & $\begin{array}{c}\text { Kinerja } \\
\text { Bisnis }\end{array}$ & $\begin{array}{c}\text { Kompetensi } \\
\text { Sosial }\end{array}$ & $\begin{array}{c}\text { Orientasi } \\
\text { Berbagi } \\
\text { Pengetahuan }\end{array}$ & $\begin{array}{c}\text { Relasional } \\
\text { Jejaring }\end{array}$ \\
\hline KB1 & $\mathbf{0 . 7 1 0}$ & 0.402 & 0.593 & 0.416 \\
KB2 & $\mathbf{0 . 8 0 2}$ & 0.592 & 0.557 & 0.540 \\
KB3 & $\mathbf{0 . 7 3 5}$ & 0.540 & 0.496 & 0.478 \\
KB4 & $\mathbf{0 . 7 2 5}$ & 0.536 & 0.544 & 0.488 \\
KB5 & $\mathbf{0 . 6 4 2}$ & 0.523 & 0.425 & 0.460 \\
\hline KS1 & 0.444 & $\mathbf{0 . 7 4 6}$ & 0.392 & 0.478 \\
KS2 & 0.513 & $\mathbf{0 . 7 8 4}$ & 0.439 & 0.414 \\
KS3 & 0.514 & $\mathbf{0 . 7 5 6}$ & 0.350 & 0.433 \\
KS4 & 0.453 & $\mathbf{0 . 7 2 6}$ & 0.255 & 0.452 \\
KS5 & 0.618 & $\mathbf{0 . 6 8 3}$ & 0.505 & 0.515 \\
KS6 & 0.532 & $\mathbf{0 . 6 2 4}$ & 0.376 & 0.351 \\
\hline OBP1 & 0.427 & 0.408 & $\mathbf{0 . 6 0 9}$ & 0.382 \\
OBP2 & 0.467 & 0.371 & $\mathbf{0 . 6 5 4}$ & 0.395 \\
OBP3 & 0.545 & 0.418 & $\mathbf{0 . 7 7 9}$ & 0.482 \\
OBP4 & 0.570 & 0.372 & $\mathbf{0 . 7 8 9}$ & 0.400 \\
OBP5 & 0.620 & 0.428 & $\mathbf{0 . 8 1 2}$ & 0.404 \\
\hline RJ1 & 0.440 & 0.423 & 0.255 & $\mathbf{0 . 6 7 9}$ \\
RJ3 & 0.515 & 0.484 & 0.431 & $\mathbf{0 . 8 3 2}$ \\
RJ4 & 0.432 & 0.442 & 0.340 & $\mathbf{0 . 7 8 3}$ \\
KJ5 & 0.565 & 0.490 & 0.595 & $\mathbf{0 . 7 1 0}$ \\
\hline & -15 & & \\
\hline
\end{tabular}

Sumber : Data yang diolah, 2017

Tabel 3. $R$ Square

\begin{tabular}{lc}
\hline & R Square \\
\hline Kinerja Bisnis & 0,698 \\
$\begin{array}{l}\text { Orientasi Berbagi } \\
\text { Pengetahuan }\end{array}$ & 0,332 \\
$\begin{array}{l}\text { Relasional Jejaring } \\
\text { Entrepreneur }\end{array}$ & 0,374 \\
\hline Sumber : data yang diah, 2017
\end{tabular}

Sumber : data yang diolah, 2017

Tabel 3 menunjukkan bahwa $R$ Square untuk variabel kinerja bisnis sebesar $0,698(69,8 \%)$ artinya bahwa kompetensi sosial, relasional jejaring dan berbagi pengetahuan cukup kuat untuk menjelaskan kinerja bisnis sedangkan $30,2 \%$ dapat dijelaskan oleh faktor-faktor lain selain ketiga konstruk tersebut. Namun pada tabel 1 menunjukkan $R$ square untuk orientasi berbagi pengetahuan dan relasional jejaring entrepreneur masingmasing 0,332 dan 0,374 hal ini menunjukan bahwa variabel laten eksogen 
memiliki pengaruh yang moderat untuk menjelaskan variabel endogennya (Chin et al.,1998). Orientasi berbagi pengetahuan dapat dijelaskan oleh variabel relasional jejaring entrepreneur sebesar 0,332 atau $33,2 \%$, selanjutnya relasional jejaring entrepreneur dapat dijelaskan oleh kompetensi sosial sebesar 0,374 atau sebesar 37,4\%.

Adapun hasil pengujian kesesuaian model menunjukkan bahwa model penelitian telah sesuai dengan data atau fit terhadap data. Hal ini dapat dilihat pada tabel 2 yang menunjukan nilai SRMR, d_ULS, d_G Chi Square dan NFI yang telah sesuai dengan cutt of yang dipersyaratkan dalam kesesuaian model (Tabel 4).
Tabel 4. Hasil Uji Kesesuaian Model

\begin{tabular}{lrrr}
\hline & $\begin{array}{c}\text { Hasil } \\
\text { Analisis }\end{array}$ & Cut Off & \multicolumn{1}{c}{ Ket } \\
\hline SRMR & 0,071 & $<0,08$ & Baik \\
d_ULS & 0,902 & $<0,95$ & Baik \\
d_G & 0,690 & $<0,95$ & Baik \\
Chi- & 103,847 & $<149,88$ & Baik \\
Square & 0,876 & $>0,80$ & Baik \\
NFI &
\end{tabular}

Sumber : Data primer diolah, 2017

\section{Hasil Pengujian Model Struktural (Inner Model)}

Pengujian inner model dilakukan untuk melihat hubungan antara konstruk dan nilai signifikansinya. Pengujian hipotesis dilakukan dengan Partial Least Square dengan program SmartPLS 3. Adapun gambar 2 menunjukkan hasil pengujian dalam penelitian.

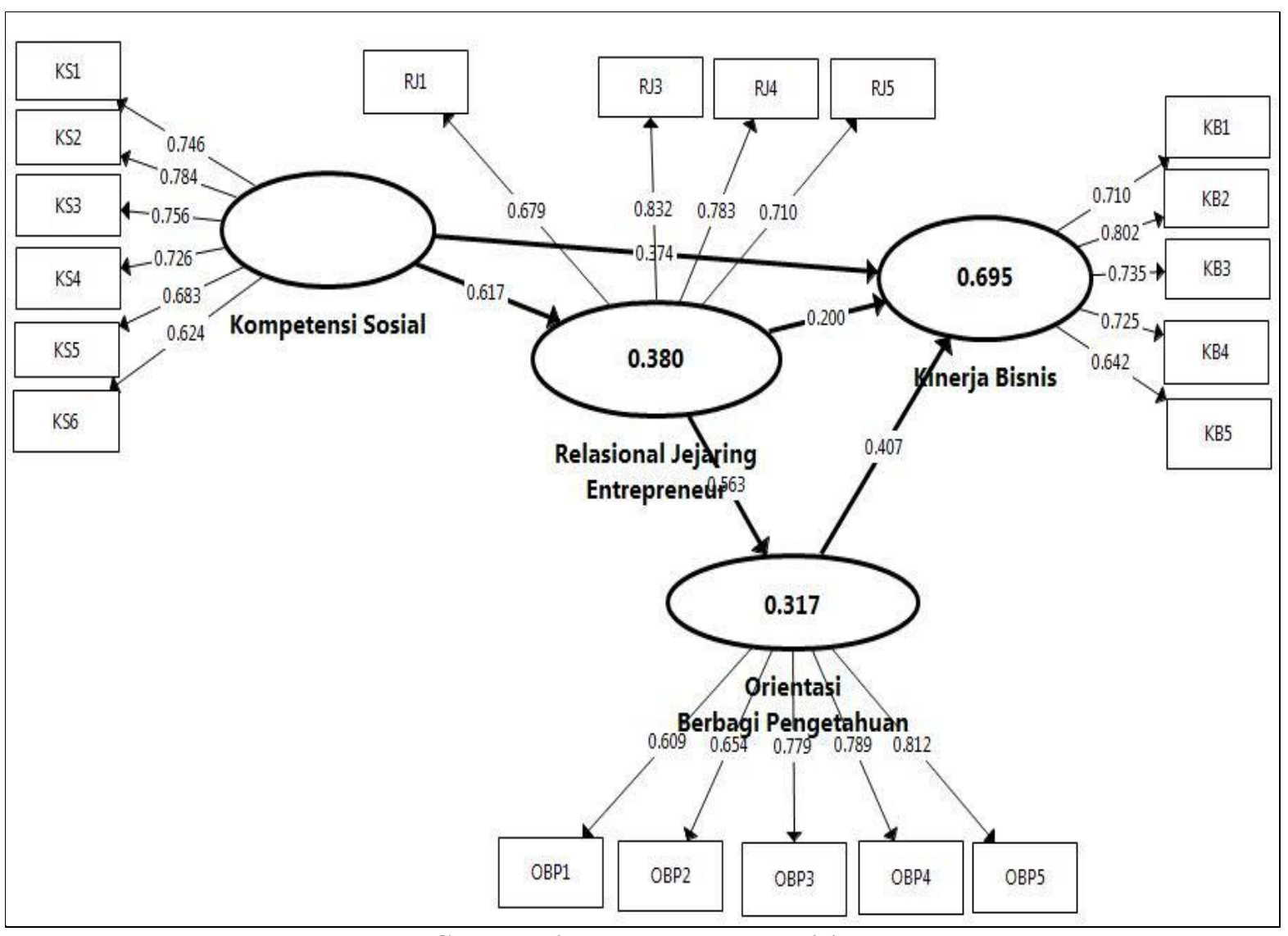

Gambar 2. Full Model Penelitian 
Pengujian untuk melihat hubungan antar konstruk atau pengujian hipotesis dapat dilihat dengan melihat koefisien parameter dan membandingkan antara nilai t-hitung dan t-tabel pada taraf signifikasi sebesar 0,05. Tabel 5 menunjukkan hasil hubungan antar konstruk atau uji hipotesis penelitian sebagai berikut:

\section{Tabel 5. Hasil Statistik Inner Model}

\begin{tabular}{lccc}
\hline $\begin{array}{c}\text { Hubungan Kausalitas } \\
\text { Konstruk }\end{array}$ & $\begin{array}{c}\text { Koefisien } \\
\text { Estimasi }\end{array}$ & $\begin{array}{c}\mathbf{t} \text { - } \\
\text { Statistik }\end{array}$ & $\begin{array}{c}\boldsymbol{p} \\
\text { Value }\end{array}$ \\
\hline $\begin{array}{l}\text { Kompetensi Sosial } \\
\rightarrow \text { Kinerja Bisnis }\end{array}$ & 0,369 & 6,141 & 0,000 \\
\hline $\begin{array}{l}\text { Kompetensi Sosial } \\
\rightarrow \text { Relasional }\end{array}$ & 0,612 & 10,433 & 0,000 \\
$\begin{array}{l}\text { Jejaring } \\
\text { Entrepreneur }\end{array}$ & & & \\
\hline $\begin{array}{l}\text { Orientasi Berbagi } \\
\text { Pengetahuan } \rightarrow\end{array}$ & 0,397 & 5,696 & 0,000 \\
Kinerja Bisnis & & & \\
\hline $\begin{array}{l}\text { Relasional Jejaring } \\
\text { Entrepreneur } \rightarrow\end{array}$ & 0,218 & 3,047 & 0,002 \\
Kinerja Bisnis & & & \\
\hline $\begin{array}{l}\text { Relasional Jejaring } \\
\text { Entrepreneur } \rightarrow\end{array}$ & & & \\
$\begin{array}{l}\text { Orientasi Berbagi } \\
\text { Pengetahuan }\end{array}$ & 0,575 & 9,961 & 0,000 \\
\hline Sumber : Data yang diolah, & & & \\
\hline
\end{tabular}

Sumber : Data yang diolah, 2017

Hasil estimasi dengan menggunakan sampel sebanyak 127, menunjukkan bahwa seluruh hubungan kausalitas yang diuji dalam penelitian ini menunjukkan nilai $\mathrm{t}$ statistik yang lebih besar dari 1,96 dengan $p$ value lebih kecil daripada 0,05. Hal ini menunjukkan bahwa seluruh hipotesis yang diajukan dalam penelitian ini diterima.

\section{Hasil Uji Indirect Effect}

Hasil uji pengaruh tidak langsung pada model penelitian ditunjukkan pada tabel 6. Pengaruh kompetensi sosial terhadap kinerja bisnis melewati relasional jejaring dan orientasi berbagi pengetahuan sebesar 0,273 dengan $\mathrm{T}$ statistik 5,531 dengan signifikansi sebesar 0,000. Pengaruh kompetensi sosial terhadap orientasi berbagi pengetahuan melewati relasional jejaring sebesar 0,352 dengan $\mathrm{T}$ statistik 6,488 dengan signifikansi sebesar
0,000. Adapun pengaruh relasional jejaring terhadap kinerja bisnis melewati orientasi berbagi pengetahuan sebesar 0,228 dengan $\mathrm{T}$ statistik 4,677 dengan signifikansi sebesar 0,000. Jadi dapat disimpukan bahwa relasional jejaring dan orientasi berbagi pengetahuan merupakan variabel mediasi atau intervening dalam model penelitian yang diajukan.

Tabel 6. Uji Pengaruh Tidak langsung

\begin{tabular}{lcr}
\hline & $\begin{array}{l}\text { Original } \\
\text { Sample }\end{array}$ & $\begin{array}{c}\text { T Statistics } \\
(\boldsymbol{p} \text { value })\end{array}$ \\
\hline $\begin{array}{l}\text { Kompetensi Sosial -> } \\
\text { Kinerja Bisnis }\end{array}$ & 0,273 & $\begin{array}{r}5,531 \\
(0,000)\end{array}$ \\
\hline $\begin{array}{l}\text { Kompetensi Sosial -> } \\
\text { Orientasi Berbagi }\end{array}$ & 0,352 & $\begin{array}{r}6,488 \\
(0,000)\end{array}$ \\
Pengetahuan & & $\begin{array}{r}4,677 \\
\text { Relasional Jejaring }\end{array}$ \\
$\begin{array}{l}\text { Entrepreneur -> } \\
\text { Kinerja Bisnis }\end{array}$ & 0,228 & $(0,000)$ \\
\hline Sumber : Data yang & & \\
\hline
\end{tabular}

Sumber : Data yang diolah, 2017

\section{Hasil Pengujian dan Pembahasan Hipotesis}

\section{Pengaruh kompetensi sosial terhadap kinerja bisnis}

Kompetensi sering digunakan sebagai alat yang akan yang menentukan tingkat keberhasilan seseorang dalam menjalankan pekerjaannya dalam posisi tertentu. Kompetensi merupakan hal penting bagi entreprenenur dan menjadi penentu yang signifikan untuk mencapai keberhasilan bisnis karena entrepenenur bereran ganda sebagai pemilik dan manajer (Meutia, 2013). Oleh karena itu kompetensi memiliki hubungan yang sangat erat dengan kinerja. Tidak terkecuali dalam lingkup perusahaan. Kompetensi sosial akan dapat berdampak pada kinerja organisasi karena kemampuan entrepreneur ini akan memudahkan entrepreneur beradaptasi dengan individu lain maupun membentuk kesan yang baik pada stakeholder organisasi (Manuela et al., 2004; Meutia, 2013).

Hasil pengujian statistik terhadap hipotesis 1 dalam penelitian ini menunjukkan nilai koefisien estimasi kompetensi sosial terhadap kinerja bisnis UKM sebesar 
0.369 dengan t hitung sebesar 6.141 dan $p$ value sebesar 0.000. Nilai-nilai tersebut telah memenuhi syarat penerimaan hipotesis yaitu $\mathrm{t}$ hitung lebih besar dari $\mathrm{t}$ tabel sebesar 1,96 pada tingkat signifikansi sebesar 0,05 dan nilai $p$ value lebih kecil dari probabilitas signifikansi 0,05. Oleh karena itu dapat disimpulkan bahwa pengaruh signifikan kompetensi sosial terhadap kinerja bisnis perusahaan telah terbukti.

Penelitian ini menyatakan bahwa kompetensi sosial dalam diri entrepreneur dibutuhkan sehingga entreprenenur mendapatkan informasi yang memadai dan dapat membantu perusahaan mencapai tujuannya atau bahkan membuka peluang usaha baru. Dalam teori RBV dan modal sosial dijelaskan bahwa kompetensi sosial merupakan aset tidak berwujud perusahaan yang akan memberikan kemudahan akses untuk mendapatkan sumber daya eksternal sehingga perusahaan memiliki keunggulan kompetitif dan mencapai kinerja bisnisnya.

Hasil penelitian ini juga menggambarkan perlunya kompetensi sosial untuk membangun relasional jejaring dengan pihak eksternal. Entrepreneur yang memiliki kompetensi sosial yang tinggi akan lebih mudah untuk mengekspresikan akan perhatian sosial di sekitarnya, lebih berperilaku simpatik dan humanistik terhadap sesama dan lebih disukai oleh individu disekitarnya. Menurut Meutia (2015) entrepreneur dengan sifat-sifat positif yang melekat dalam dirinya akan memudahkan mereka untuk melakukan interaksi dengan lancar, menciptakan hubungan sosial, dan menciptakan arus komunikasi tertutup yang akan mempengaruhi kinerja bisnis.

\section{Pengaruh Kompetensi Sosial terhadap Relasional Jejaring Entrepreneur}

Kompetensi sosial adalah keseluruhan efektifitas yang dimiliki oleh entrepreneur dalam berinteraksi dengan orang lain (Spence, 1999). Interaksi sosial entrepreneurship memungkinkan seorang entrepreneur meningkatkan perkembangan bisnisnya (Meutia, 2012; Ismail, 2015). Interaksi sosial dalam kerjasama akan membuat responden dan rekan bisnisnya untuk menciptakan hubungan keluarga (Meutia, 2012; Ismail, 2015). Kompetensi sosial memungkinkan entrepreneur untuk mengekspresikan kemampuannya dalam membangun hubungan sosial melalui pengembangan kompetensi relasional dan interaksi sosial yang berbasis pada semangat keluarga, sehingga bisa membangun jejaring bisnis dengan lingkungan bisnisnya.

Hasil pengujian statistik terhadap hipotesis 2 menunjukkan nilai koefisien estimasi kompetensi sosial terhadap relasional jejaring entrepreneur sebesar 0,612 dengan t hitung sebesar 10,433 dan $p$ value sebesar 0,000. Nilai-nilai tersebut telah memenuhi syarat penerimaan hipotesis yaitu $\mathrm{t}$ hitung lebih besar dari $\mathrm{t}$ tabel sebesar 1,96 pada tingkat signifikansi sebesar 0,05 dan nilai $p$ value lebih kecil dari probabilitas signifikansi 0,05 . Oleh karena itu dapat disimpulkan pengaruh signifikan kompetensi sosial terhadap relasional jejaring entrepreneur telah terbukti.

Hasil penelitian empiris membuktikan bahwa entrepreneur UKM yang memiliki kompetensi sosial mampu membentuk jejaring dengan pihak eksternal atau stakeholder. Entrepreneur membangun usahanya dengan sikap penuh rasa empati, kepedulian, ekspresi emosi yang positif dan berperilaku prososial menyebabkan mereka lebih diterima di semua kalangan. Hasil penelitian Meutia (2015) memperlihatkan bahwa entrepreneur dengan kompetensi sosial akan lebih dapat diterima oleh lingkungan sekitarnya, sehingga akan memberi manfaat dalam menciptakan arus komunikasi dan informasi yang berdampak positif bagi diri entrepreneur.

\section{Pengaruh Relasional Jejaring Entre- preneur terhadap Kinerja Bisnis}

Perkembangan kinerja bisnis UKM merupakan hal krusial yang akan 
mempengaruhi pangsa pasar lokal maupun global. Upaya pengembangan hubungan jejaring bisnis sangat penting terutama untuk memperbaiki kegiatan ekonomi, manajemen bisnis yang efisien, dan memperluas pasar. Kemampuan UKM untuk membangun jejaring akan membawa dampak positif seperti informasi bisnis yang lebih besar dan kemampuan beradaptasi dengan lingkungan bisnis. Hal ini akan mempengaruhi sumber daya unik yang dapat dikumpulkan perusahaan untuk mencapai kinerja bisnisnya. Relasional jejaring yang dibangun oleh entrepreneur akan menciptakan sinergy dari kerja sama bisnis yang indipenden sehingga mendapatkan manfaat yang lebih besar.

Adapun hasil pengujian statistik terhadap hipotesis 3 menunjukkan nilai koefisien estimasi relasional jejaring entrepreneur terhadap kinerja bisnis perusahaan sebesar 0,218 dengan t hitung sebesar 3,047 dan $p$ value sebesar 0,002. Nilai-nilai tersebut telah memenuhi syarat penerimaan hipotesis yaitu $t$ hitung lebih besar dari t tabel sebesar 1,96 pada tingkat signifikansi sebesar 0,05 dan nilai pvalue lebih kecil dari probabilitas signifikansi 0,05 . Oleh karena itu dapat disimpulkan pengaruh signifikan relasional jejaring entrepreneur terhadap kinerja bisnis perusahaan telah terbukti.

Hasil penelitian ini memperlihatkan bahwa relasional jejaring yang dimiliki entrepreneur akan berdampak pada pangsa pasar, profit margin, pertumbuhan penjualan, pangsa maupun return yang diperoleh UKM. Penelitian yang dilakukan oleh Baron dan Markman (2003) juga menyebutkan bahwa jejaring bisnis yang lebih luas akan membantu kemudahan akses perusahaan terhadap halhal penting yang dibutuhkan perusahaan dalam menjalankan aktivitas bisnisnya, sehingga perusahaan akan mencapai keberhasilan dalam kinerjanya.

Pada teori modal sosial menjelaskan bahwa relasional jejaring akan memudahkan entrepreneur untuk mendapatkan sumber daya unik melalui adanya penghematan biaya sehingga hal akan mempengaruhi kesuksesan perusahaan. Menurut Meihua dan Jianhui (2015), relasional jejaring adakalanya membantu perusahaan untuk menciptakan skala ekonomi sehingga perusahaan dapat mengurangi biaya dan mencapai keuntungan yang optimal. Jejaring bisnis akan memberi nilai bagi entrepreneur untuk mendapatkan akses modal sosial yang ditanamkan dalam jejaring tersebut, dimana jejaring itu nantinya akan berfungsi sebagai sarana entrepreneur untuk mendapatkan sumber daya eksternal yang dibutuhkan untuk aktivitas bisnis perusahaan (Lubatkin et al.,2003) .

\section{Pengaruh Relasional Jejaring Entre- preneur terhadap Orientasi Berbagai Pengetahuan}

Kinerja perusahaan sangat bergantung pada berbagai pihak yang berinteraksi dengannya. Perusahaan harus mampu untuk mengembangkan dan mengelola hubungan dengan pemasok utama, pelanggan dan organisasi lainnya. Perusahaan akan menangani secara efektif interaksi antara hubungan ini dengan kompetensi inti yang dimilkinya. Manajemen pengetahuan menjadi faktor kunci dalam keberhasilan perusahaan, dengan berbagi pengetahuan menjadi elemen intinya. Studi tentang transformasi pengetahuan tacit dan kerja sama organsasi telah memperlihatkan adanya konfigurasi keterpaduan relasional yang memiliki dampak penting bagi berbagi pengetahuan dalam suatu organisasi (Jian dan Wang,2013).

Menurut Nahapiet dan Ghoshal, (1998), Teori modal sosial mengacu pada seperangkat sumber daya sosial yang berharga yang tertanam dalam hubungan sosial. Pandangan bahwa teori modal sosial dapat mempengaruhi perilaku berbagi pengetahuan secara langsung juga didukung oleh Kim et al.,(2013). Ketiga dimensi modal sosial, yaitu struktural, relasional dan kognitif, memiliki pengaruh secara langsung baik sumbangan 
pengetahuan maupun pengumpulan pengetahuan.

Hasil pengujian statistik terhadap hipotesis 4 menunjukkan nilai koefisien estimasi relasional jejaring entrepreneur terhadap orientasi berbagi pengetahuan sebesar 0,575 dengan $t$ hitung sebesar 9,961 dan $p$ value sebesar 0,000 . Nilainilai tersebut telah memenuhi syarat penerimaan hipotesis yaitu $t$ hitung lebih besar dari t tabel sebesar 1,96 pada tingkat signifikansi sebesar 0,05 dan nilai $p$ value lebih kecil dari probabilitas signifikansi 0,05 . Oleh karena itu dapat disimpulkan pengaruh signifikan relasional jejaring entrepreneur terhadap orientasi berbagi pengetahuan telah terbukti.

Penelitian ini menggambarkan bahwa modal sosial memiliki hubungan dengan modal manusia. Interaksi individu dengan individu lain akan mendorong terjadinya berbagi pengetahuan diantara keduanya. Atau dapat dikatakan bahwa berbagi pengetahuan dapat terjadi apabila terdapat adanya interaksi antara penyedia pengetahuan dan penerima pengetahuan. Manfaat yang muncul dari proses berbagi pengetahuan tentu saja akan membawa dampak positif bagi individu yang terlibat didalamnya maupun organisasi dimana individu tersebut berada. Seperti yang penelitian yang dilakukan Borges (2013) menyebutkan bahwa jejaring akan mempengaruhi perilaku berbagi pengetahuan. Hal ini didasarkan adanya pemahaman bahwa individu akan cenderung lebih nyaman melakukan berbagi pengetahuan dengan siapa saja yang memiliki kedekatan dengan dirinya.

\section{Pengaruh Orientasi Berbagai Penge- tahuan terhadap Kinerja Bisnis}

Berbagi pengetahuan dalam suatu organisasi membawa peran yang sangat penting. Berbagi pengetahuan dapat menumbuhkan kreativitas dan inovatif bagi individu yang terlibat di dalamnya. Sedangkan inovasi dan kreativitas merupakan urat nadi yang sangat penting bagi eksistensi UKM.
Penelitian tentang berbagi pengetahuan mengungkapkan bahwa berbagi pengetahuan adalah proses rekombinasi dan evolusi pengetahuan (Lee dan Cole, 2003) dan globalisasi lebih menyukai organisasi-organisasi yang mampu menciptakan dan berbagi pengetahuan secara lebih efektif dan efisien daripada pesaing mereka (Porter, 1990). Jadi bisa dikatakan bahwa berbagi pengetahuan berkaitan dengan kinerja dan daya saing yang telah berjalan lama.

Dasar berbagi pengetahuan adalah membuat mudah terjadinya transfer pengetahuan dari satu individu ke individu lain. Individu akan mendapatkan pengetahuan dari luar dan kemudian mengadopsinya untuk menunjang keberhasilan pekerjaan mereka. Berbagi pengetahuan sangat penting bagi karyawan perusahaan karena mereka akan mendapatkan pengetahuan dari pengalaman yang dikumpulkan oleh rekan kerja di antar divisi maupun dari organisasi luar (Madsen et al.,2003).

Hasil pengujian statistik terhadap hipotesis 1 menunjukkan nilai koefisien estimasi orientasi berbagi pengetahuan terhadap kinerja bisnis perusahaan sebesar 0.397 dengan $t$ hitung sebesar 5.696 dan $p$ value sebesar 0.000. Nilai-nilai tersebut telah memenuhi syarat penerimaan hipotesis yaitu $\mathrm{t}$ hitung lebih besar dari $\mathrm{t}$ tabel sebesar 1,96 pada tingkat signifikansi sebesar 0,05 dan nilai $p$ value lebih kecil dari probabilitas signifikansi 0,05 . Oleh karena itu dapat disimpulkan pengaruh signifikan orientasi berbagi pengetahuan terhadap kinerja bisnis perusahaan telah terbukti.

Hasil penelitian ini menggambarkan bahwa berbagi pengetahuan yang terjadi pada lingkungan UKM akan membawa dampak positif bagi kinerja UKM. Menurut Lee et al., (2005), tujuan dasar berbagi pengetahuan adalah untuk mentransfer pengetahuan dari orang ke orang, sehingga individu juga harus membagikan pengalaman mereka kepada rekan kerja dan anggota tim mereka 
(Madsen et al.,2003). Berbagi pengetahuan diantara anggota organisasi pada akhirnya akan membawa konsekuensi bagi produktivitas dan kinerja perusahaan.

\section{PENUTUP}

\section{Kesimpulan}

Berdasarkan analisis yang dilakukan pada 127 UKM sektor manufaktur di Kota Surakarta yang terdiri dari 36 UKM Garment, 57 UKM Makanan dan Minuman dan 24 UKM kerajinan, maka dapat disimpulkan bahwa relasional jejaring entrepreneur dapat berperan sebagai katalisator dalam meningkatkan kinerja bisnis pada UKM sektor manufaktur di Kota Surakarta. Adapun kesimpulan ini diambil berdasarkan pada hasil analisis sebagai berikut :

1. Relasional jejaring entrepreneur dan orientasi berbagi pengetahuan dapat memediasi pengaruh antara kompetensi sosial dan kinerja bisnis.

2. Kompetensi sosial memiliki pengaruh pada kinerja bisnis. Hasil penelitian ini sejalan dengan penelitian Verbeke et al.,(2011) maupun Yang dan $\mathrm{Wu}$ (2014). Kompetensi sosial dapat berdampak pada kinerja organisasi karena kemampuan tersebut akan memudahkan entrepreneur beradaptasi dengan individu lain maupun membentuk kesan yang baik pada stakeholder. Kompetensi sosial entrepreneur meliput kemampuan berkomunikasi, kerja sama, kontrol diri, kemampuan menemukan solusi dan menyelesaikan konflik. Oleh sebab itu entrepreneur dengan kompetensi sosial tinggi akan lebih mudah mencapai kinerja yang tinggi.Hal ini berdampak pada kinerja organisasi.

2. Kompetensi sosial berpengaruh pada relasional jejaring entrepreneur. Hasil penelitian ini didukung oleh penelitian Baron (2003), Meutia (2013,2015). Entrepreneur yang memiliki kompetensi sosial yang baik cenderung memiliki sikap prososial dan bersikap lebih simpatik sehingga lebih disukai dan dengan mudah melakukan interaksi dengan lingkungan sekitar.

3. Relasional jejaring entrepreneur berpengaruh pada kinerja bisnis. Hasil penelitian konsisten dengan penelitian Biggs dan Shah (20060, Watson (2007), Smirnova et al.,(2011), Zohdi et al.,(2013) maupun Meihua dan Jianhui (2015). Relasional jejaring akan menciptakan sinergi dengan pihakpihak terkait dan memberi akses untuk mendapatkan sumber daya eksternal yang dibutuhkan sehingga akan meningkatkan kinerja perusahaan.

4. Relasional jejaring entrepreneur berpengaruh pada orientasi berbagi pengetahuan. Hasil penelitian konsisten dengan penelitian Wang dan Noe (2010), Chai et al.,(2012), Borges, (2013), Jian dan Wang (2013), Salehi et al. (2014) dan Tangaraja et al.,(2015). Individu dalam perusahaan dengan ikatan interpersonal yang kuat akan mudah melakukan berbagi pengetahuan karena adanya situasi kerja nyaman dan kondusif. Salah satu dimensi modal sosialyaitu relasional memiliki pengaruh langsung pada sumbangan pengetahuan maupun pengumpulan pengetahuan dalam perusahaan.

5. Orientasi berbagi pengetahuan berpengaruh pada kinerja bisnis. Hasil penelitian konsisten dengan penelitian Chou et al.,(2009), Lee et al.,(2013), Vij (2014). Berbagi pengetahuan adalah dasar kolaborasi pengetahuan dalam perusahaan. Bagi anggota perusahaan, berbagi pengetahuan akan meningkatkan produktivitas yang akan mendukung kinerja peruahaan. Berbagi pengetahuan dapat membantu perusahaan menyelesaikan masalah dengan tindakan solusi inovatif sehingga masalah perusahaan dapat tertangani dengan baik dan kinerja perusahaan dapat tercapai sesuai dengan target yang ditetapkan. 


\section{Implikasi}

Implikasi penelitian yang bisa diberikan dari hasil penelitian ini adalah bahwa UKM sebagai penyedia lapangan pekerjaan bagi berjuta-juta penduduk di Indonesia perlu diperhatikan eksistensinya. Pemerintah dapat mengambil langkahlangkah nyata untuk dapat meningkatkan kompetensi sosial sehingga dapat memperluas relasional jejaring, berbagi pengetahuan dan kinerja UKM. Relasional jejaring entrepreneur yang handal diharapkan menjadi landasan bagi UKM untuk memperkuat berbagi pengetahuan sehingga dapat meningkatkan kinerja bisnis UKM. Hal ini perlu dilakukan karena UKM merupakan aspek penting bagi pembangunan ekonomi di Indonesia yang kompetitif sehingga diharapkan mereka dapat bersaing aktif dalam pasar global. Selain itu bagi UKM, hasil penelitian ini sebagai bahan masukan untuk meningkatkan kompetensi sosial yang dimiliki UKM sehingga dapat meningkatkan relasional jejaring dan berbagi pengetahuan pada UKM dan pada akhirnya akan berdampak semakin baiknya kinerja UKM. Dengan kinerja yang baik maka diharapkan UKM dapat lebih eksis dalam pasar domestik dan mampu bersaing secara imbang dalam pasar internasional.

\section{Saran}

Adapun saran yang bisa diberikan adalah perlunya memperluas frame sampling penelitian untuk meningkatkan kemampuan generalisasi dari model relasional jejaring entrepreneur dalam penelitian yang diajukan. Selain itu penelitian selanjutnya perlu menggali lebih dalam lagi mengenai teori modal sosial yang mendasari model relasional jejaring entrepreneur. Hal ini dilakukan dengan mencoba mengintegrasikan model yang ada dengan konsep kepercayaan. Kepercayaan yang dibangun oleh pihakpihak yang terlibat akan memperkuat interaksi interpersonal dan memperlancar komunikasi diantara mereka sehingga akan memberi peluang terjadinya hubungan yang saling menguntungkan. Oleh karena itu konsep kepercayaan dipandang dapat memperkuat model relasional jejaring entrepreneur untuk membangun kinerja pada UKM.

\section{UCAPAN TERIMA KASIH}

1. Direktorat Riset dan Pengabdian Masyarakat, Direktorat Jenderal Penguatan Riset dan Pengembangan Kementerian Riset, Teknologi, dan Pendidikan Tinggi.

2. Kopertis VI Wilayah Jawa Tengah.

\section{DAFTAR PUSTAKA}

Berney, J. (1991). Firm resources and sustained competitive advantage. Journal of Management, 17(1), 99-120.

, (2007). Gaining and sustaining competitive advantage (3rd ed.). Upper Saddle River, NJ: Prentice-Hall.

Baron, R.A., \& Markman, G.D. (2003). Beyond Social Capital: The Role of Entrepreneurs' Social Competence in Their Financial Success. Journal of Business Venturing, 18 (1), 41-60.

Biggs, Tyler \& Shah, M.K. (2006). African SMES, networks, and manufacturing performance. Journal of banking and finance, $l$ (30), 3043 - 3066.

Bruderl, J., \& P. Preisendorfer. (1998). Network support and the success of newly founded businesses. Small Business Economics, 19, 213-225.

Borges, R. (2013). Tacit knowledge sharing between IT workers: the role of organizational culture, personality, and social environment. Management Research Review, 36(1), 89-108.

Bourdieu, P. (1986). The forms of capital, in J.E. Richardson (Ed.) Handbook of Theory of research for the sociology of education (pp.241-258). New York: Greenwood Press. 
Chai, S., Das, S. \& Rao, H.R. (2012). Factors affecting bloggers' knowledge sharing: an investigation across gender. Journal of Management Information Systems. 28(3), 309-342.

Chrisholm, A., \& Nielsen, K. (2009). Social capital and the resource-based view of the firm. International Studies of Management and Organisation, 39(2), 7-32.

Chou, S.-W., Min, H.-T., Chang, Y.-C. \& Lin, C.-T. (2009). Understanding continuance intention of knowledge creation using extended expectation confirmation theory: an empirical study of Taiwan and China online communities. Behaviour \& Information Technology, 29 (6), 557-570.

Coleman, J.S. (1998). Social capital in the creation of human capital. The American journal of sociology,94, 95120.

Davidsson, P., \& Honig, B. (2003). The role of social and human capital among nascent entrepreneurs. Journal of Business Venturing, 18, 301-331.

Dodd, S., Jack S., \& Anderson A., (2002). Scottish Entrepreneurial Networks in the International Context. International Small Business Journal,20(2), 213-219.

Ellis, P. (2010). Social ties and international entrepreneurship: Opportunities and constraints affecting firm internationalization. Journal of International Business Studies, 41(1), 99-127.

Eskildsen, J., Westlund, A, \& Kristensen, K., (2003). The predictive power of intangibles, Measuring Business Excellence, 7(2).
Fafchamps, M., \& Minten, B. (2002). Social capital and the firm: evidence from agricultural traders in Madagascar. In van Bastelaer, T., (Eds.), The Role of Social Capital in Development, (pp.125-154), Melbourne: Cambridge University Press.

Ghozali, I. (2015). Partial Least Squares : Konsep, Teknik Dan Aplikasi Menggunakan Program SmartPLS 3.0. Undip. ISBN: 979-704.300.2

Grootaert, C. (1998). Social capital: the missing link? The World Bank Social Capital Initiative. Working Paper No. 3. Washington D.C: The World Bank.

Hakim, A. (2015). Contribution of Competence Teacher (Pedagogical, Personality, Professional Competence and Social) On the Performance of Learning. The International Journal of Engineering And Science,4 (2),1-12.

Hirsch, (2009). Entrepreneurship, 8th Edition. McGraw-Hill/Irwin.

Horvat, J., K.Sharma \& S. Bobek. (2015). Knowledge Sharing and Performance Appraisal of Employees: a Pilot Case Study. Review of Integrative Business and Economics Research, 4 (1), 62-73.

Ishtiaque AA., Khan H., Alter S., \& Fatima ZK. (2007). Perception Analysis of Balance Scorecard: An Aplication over a Multinational Corporation of Bangladesh. Journal of Business Studies, 28 (2), 238-268.

Ismail, T. (2015). Cultural Control, Creativity, Social Capital and Organizational Performance: Empirical Study of Small to Medium Sized Enterprises (SME) In Indonesia. International Journal of Entrepreneurship. 19 (1). 
Jalote, P. (2003). Knowledge infrastructure for project management. In Managing Software Engineering Knowledge (pp. 361-375). Springer. Akses dari http://link.springer.com /chapter/10.1007/978-3-662-051290_17

Jian , Z., \& C. Wang. (2013). The impacts of network competence, knowledge sharing on service innovation performance: Moderating role of relationship quality. Journal of Industrial Engineering and Management, 6 (1), 25-49.

Kale, P., \& Singh, H. (2007). Building Firm Capabilities Through Learning: the Role of the Alliance Learning Process in Alliance Capability and Firm-level Alliance Success. Strategic Management Journal, 28(10), 9811000.

Khan, K., Nemati, A.R., \& Iftikhar, M., (2011). Impact of Corporate Governance on Firm Performance: Evidence from the Tobacco Industry of Pakistan. International Research Journal of Finance and Economics, ISSN 1450-2887, Issue 61

Kim, T.T., Lee, G., Paek, S., \& Lee, S., (2013). Social capital, knowledge sharing and organizational performance: What structural relationship do they have in hotels?. International Journal of Contemporary Hospitality Management, 25(5), $683-704$

Lages, L., Silva, G., Styles, C., \& Pereira, Z. (2009). The NEP scale: A measure of network export performance. International Business Review, 18(4), 344-356.

Lee, K., Lee, S., \& Kang, I. (2005). KMPI: measuring knowledge management performance. Information and Management, 42(3),469-482.
Lee, G., \& Cole, R. (2003). From a firmbased to a community-based model of knowledge creation: the case of the Linux kernel development. Organization Science, 14(6), 633-649.

Lin, C. P., (2007). To Share or Not to Share: Modeling Tacit Knowledge Sharing, Its Mediators and Antecedents. Journal of Business Ethics, 70 (4), 411428.

Lin, N. (1999). Building a network theory of social capital. Connections, 22 (1), 2851.

Locket, A., Thompson, S., \& Morgenstern, U. (2009). The development of the resourcebased view of the firm: A critical appraisal. International Journal of Management Reviews, 11(1), 9-28.

Lubatkin, J., Florin, M., \& Schulze, W. (2003). A social capital model of highgrowth ventures. Academy of Management Journal, 46:374-396.

Lukiastuti, F., (2012). Pengaruh Orientasi Wirausaha Dan Kapabilitas Jejaring Usaha Terhadap Peningka Tan Kinerja Ukm Dengan Komitmen Perilaku Sebagai Variabel Interviening (Studi Empiris pada Sentra UKM Batik di Sragen, Jawa Tengah). Jurnal Organisasi dan Manajemen, 2(8).

Madsen, T., Mosakowski, E., \& Zaheer, S. (2003). Knowledge retention and personnel mobility: the nondisruptive effects of inflows of experience. Organization Science, 14(2), 173-191.

Manuela, N., Weiss H, Brush, C.G., \& Baron R.A., (2004). Putting Your Best Foot Forward? Assessments of Entrepreneurial Social Competence from Two Perspectives. The Journal of Private Equity, Fall 
Mathew, M., Kumar, D., \& Perumal, S.,(2011). Role of Knowledge Management Initiatives in Organizational Innovativeness: Empirical Findings from the IT Industry. Vikalpa, $36(2), 31$.

Mason, C, \& R. Harrison, (2001), Auditioning For Money: What Do Investors Look For at the Initial Screening Stage?, In R.D. Hisrich, and E. Hacker, eds. Proceedings of the Entrepreneurial Finance Workshop, Jonkoping, Sweden: Jonkoping International Business School, pp. 155176.

Meihua, YIN., \& Jianhui, WU. (2015). An Empirical Study on Strategic Network, Relational Capability and Operating Performance of Agricultural Enterprise. Asian Agricultural Research, 7(11): 511.

Meutia, (2013). Entrepreneurial Social Competence and Entrepreneurial Orientation to Build SME's Business Network and Business Performance. International Journal of Social Science and Humanity, 3 (4).

(2015). The Relationship Between Entrepreneurship Social Competence And Marketing Performance In Indonesian Smes: The Role Of Business Networking And Product Innovation. IJABER, 13 (7), 5357-5373

Nakata, C., Z. Zhu. \& M.L. Kraimer. (2008). The Complex Contribution of Information Technology Capability to Business Performance. Journal of Managerial Issues. 20(4),485-50.

Nahapiet, J., \& S. Ghoshal. (1998). Social Capital, Intellectual Capital, and The Organizational Advantage. The Academy of Management Review, 23 (2):242-266.
Newbert, S. (2007). Empirical research on the resource-based view of the firm: An assessment and suggestions for future research. Strategic Management Journal, 28(2), 121-146.

Pollard, D., \& Jemicz, M. (2010). Social capital theory and the internationalisation process of Czech SMEs. International Journal of Economics and Business Research, 2(3/4), 210-229.

Porter, M. E. (1990). The competitive advantages of nations. London.

Roxas, H.,B \& Chadee, D. (2011). A Resource-Based View Of Small Export Firms' Social Capital In A Southeast Asian Country. Asian Academy of Management Journal, 16(2), 1-28.

Salehi, P., Mohd Rasdi, R. \& Ahmad, A. (2014). Personal and environmental predictors of academics' work-family enrichment at Malaysian research universities. The Asia Pacific Education Researcher, Springer, available at: DOI number: (10.1007/s40299-014-0190-5).

Smirnova M, Naudé P, Henneberg SC, Mouzas S, \& Kouchtch SP. (2011). The impact of market orientation on the development of relational capabilities and performance outcomes: The case of Russian industrial firms. Industrial Marketing Management, 40, 44-53.

Stamatov, R., \& Sariyska, S. (2015). Social Competence - Structure And Opportunities For Development, Proceeding of The Interdisciplinary Symposium, June 3rd to 5th, Plovdiv Bulgaria.

Street, C.T., \& Cameron, A.F. (2007). External Relationships and the Small Business: A Review of Small Business Alliance and Network Research. Journal of Small Business Management,45(2),239-266. 
Tangaraja, G., R.M. Rasdi., M. Ismail \& B.A. Samah. (2015). Fostering knowledge sharing behavior among public sector managers: a proposed model for the Malaysian public service. Journal Of Knowledge Management,19(1), 121-140.

Taylor, D.W. \& R. Thorpe. (2004). Entrepreneurial learning: A process of co-participation. Journal of Small Business and Enterprise Development,11(2),203-211.

Wang, S., \& Noe, R.A. (2010). Knowledge sharing: a review and directions for future research. Human Resource Management Review, 20(2),115-131.

Watson, J. (2007). Modeling the relationship between networking and firm performance. Journal of Business Venturing, 22 (6), 852-874.

Woolcock, M. (1998). Social capital and economic development, toward a theoretical synthesis and policy framework. Theory and Society, 27 (2), 151-208.

Verbeke, W., Dietz, B. \& Verwaal, E. (2011). Drivers of sales performance: A contemporary meta-analysis. Have salespeople become knowledge brokers?. Journal of the Academy of Marketing Science, 39(3), 407-428.

Vij, S., \& Bedi, H.S. (2012). Relationship Between Entrepreneurial Orientation and Business Performance: A Review of Literature. Journal of Business Strategy, 9(3),17-31.

Vissa, B. (2013). Agency in Action: Entrepreneurs' Networking Styleand Initiation of Economic Exchange. Organization Science. Special Issue On Genesis and Dynamics of Organization Networks.
Yang, D.J., \& M.J. Wu. (2014). Does Customer Trust Play a Mediating Role Between Salesperson Competence and Performance? International Journal of Management, Economics and Social Sciences, 3(2), 100-121.

Zaqout, F., \& Abbas., M. (2012). Towards a model for understanding the influence of the factors that stimulate university students' engagement and performance in knowledge sharing. Library Review, 61 (5), 345-361.

Zhu, Zhen., \& Nakata, C., (2007). Reexamining The Link Between Customer Orientation And Business Performance: The Role Of Information Systems. Journal of Marketing Theory and Practice, 15 (3), 187.

Zohdi, M., R.Shafeai., \& R.Hashemi., (2013). Influence of relational capabilities on Business performance Case of: Kermanshah Industrial city SMEs. International Research Journal of Applied and Basic Sciences, 4 (3), 589596. 